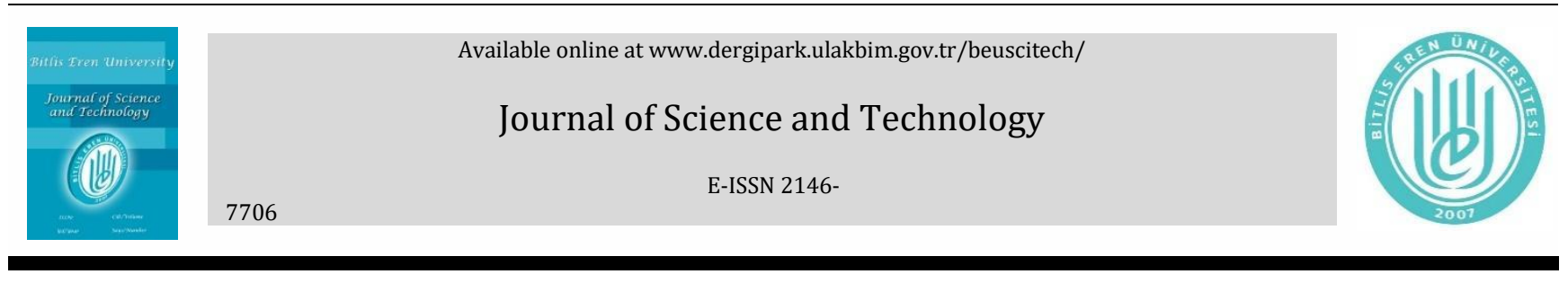

\title{
Structural analysis of Ahlat Emir Bayındır Bridge
}

\author{
Ercan Işık ${ }^{a}$, Barış Antep ${ }^{b}$ İbrahim Baran Karaşinc* \\ a Bitlis Eren University, Department of Civil Engineering, TR-13000, Bitlis Turkey \\ b Bitlis Eren University, Graduate School of Natural and Applied Sciences, Department of Civil Engineering, TR-13000, Bitlis, Turkey \\ c Dicle University, Department of Civil Engineering, TR-21000, Diyarbakır Turkey
}

\section{A R T I C LE IN F O}

\section{Article history:}

Received 19 April 2018

Received in revised form 18 May 2018

Accepted 23 May 2018

\section{Keywords:}

Ahlat

Structural analysis

Emir Bayındır Bridge

Seismic behavior

\section{A B S T RACT}

There are many historic buildings belongs to many civilizations in the Ahlat province. The fact that these structures survive for a very long time is directly related to the construction techniques of these structures. Emir Bayındır Bridge is one of the buildings that could stay solid. With this study, it is aimed to investigate the behavior of the bridge under earthquake effect. First of all, general information is given about the bridge. In this study, structural analyzes were carried out for the Ahlat Emir Bayındır Bridge after on-site inspections. Information about the damage that occurred over time in the bridge is given in this study. Observation based structural analysis form has been created for the bridge. A finite element model of the bridge was created with the help of on-site measurements. Analyzes were made for the created finite element model in different load cases. The obtained results were interpreted and recommendations were made.

\section{Introduction}

Historical monuments are priceless cultural assets that link the past with the future. At the same time, historical structures are also an indicator of society's engineering accumulations, artistic understandings and economic situations. The Van Lake basin has been home to many civilizations such as the Seljuk and Ottoman civilizations in the historical process. Historical buildings and cultural values left behind by many civilizations in the basin have been carried to today. There are many historic buildings were built in ancient times in the basin, which are restored and still being used. The Ahlat district is one of the centers that hosted many civilizations in this basin. (Işık et al. 2016).

There are many different historical buildings belong to different civilizations in Ahlat. Historical buildings are one of the essential elements of cultural heritage. Protection of such structures and transferring them to future generations is one of the important problems of today. The operations to be done with such structures are directly related to many different disciplines. Studies of such structures have an important place, nowadays. (Ișlk et al., 2017; Ișık et al., 2016a; Işık et al 2016b; Karaşin and Işık, 2016).

The standing of historical buildings for centuries is directly related to the construction technologies of them and material properties used in the construction. In this context, the structural analysis of such structures is an important engineering activity. Structural analysis software are widely used in structural analysis, today. The finite element method is used while the analysis and calculations carrying out for the historical buildings. The first step of using this method is the numerical modeling of the historical structure. Numerical modeling can be named as the transformation of the properties of a structure into mathematical expressions.

In this study, Emir Bayındır Bridge has been taken into consideration which is located in Ahlat and has a significant place in its time. General information about the historical bridge is

\footnotetext{
* Corresponding Author

Tel.: +0 5533345776

E-mail address: ibkarasin@beu.edu.tr
} 
presented in first part of the study. The model of the bridge was created by on-site inspection and measurements. The second part contains the detailed remarks about the causes and consequences of the damages on the bridge. Observation based structural analysis form created for the bridge was filled. Repetitively filling of this form on different dates over time will add a special importance to the traceability of historical structures. Formed stresses are obtained by applying different load cases to the bridge which created by finite elements method. Hereby, it is aimed to have knowledge about earthquake behavior of such structures.

\section{Method}

Seismic researches on historical structures have an important place in order to transfer the historical heritage to the next generations, nowadays. There are many studies in the literature about this topic (Hadzima-Nyarko et al., 2017; Erdil et al., 2018; Hadzima-Nyarko et al., 2016; Backer et al., 2018; Uğurlu et al., 2017; Özbek et al., 2017; Preciado et al., 2015: Işık et al., 2018; Mutlu and Şahin, 2016). In all of these studies, seismic behaviors of different structures in different regions have been tried to be determined. For this study, firstly the detailed information about Emir Bayındır Bridge will be presented.

\subsection{Emir Bayındır Bridge}

The bridge located in the district of Harabeșehir is built on the stream which separates the neighborhood. The stream is called Taht-ı Süleyman / Harabeşehir / Keş stream by local names. It is located to the west of Bayındır Mosque and the dome. It reflects the civil architectural characteristics of the Akkoyunlu people who dominated the region in the 15th century. The bridge, which belongs to the Akkoyunlu period, is in the foreground with stairs made to allow the passage of caravans and pedestals at that time although it is small. The name of the bridge was come from Emir Bayındır, who built the bridge. It is built of cut stone entirely. It is a saple of Single-eyed bridge. The bridge was repaired in 1954. The eastern side of the bridge is in the arched section and it is built lateraled to the side without a straight line. (Islam encyclopedia, 2017; Beygu, 1932; Tabak, 1972; Çulpan, 1975; Culture Portal, 2017).

The railings on the side of the bridge were constructed gradually according to the bridge slab. There are eight steps, 4 on downstairs and 4 on upstairs, on the bridge slab in total. Stairs are used in entrance and exit of the bridge. The bridge was built from Ahlat Stone, which is unique to the city of Ahlat. This is a beautiful example of pointed arched bridges. Since the bridge is narrow and stepped, it is used only by the pedestrians today (Figure 1).

Observation based structural analysis will be done to give information about the current state of historical structures before proceeding with detailed structural analysis. The purpose of observation-based structural analysis is to provide information about the damage and deformations that occur in the structure as well as revealing the current state of the structure. For this purpose, all historical structures mentioned in previous chapters have been inspected on site. Damage to the buildings and the causes of these damages have been tried to be explained.

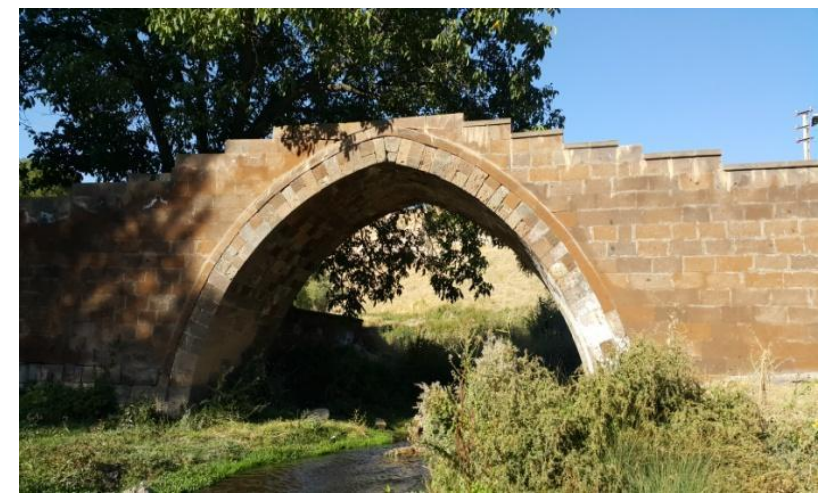

Figure 1. Emir Bayındır Bridge

Ahlat stone was used in the construction of the bridge. (Bakış et al., 2014). Today, the structure is used for transportation purposes and it is closed to vehicle traffic because it is narrow and stepped. The distribution of the structural system elements is uniform. The bridge was damaged due to treasure searching and street writing of the people of the region. Depending on the time, various damage has occurred due to other environmental factors such as wear and tear. Ahlat stone, which is belongs to the group of natural stones, was used on the walls, covering and slab of this structure. It has get through the Van earthquake without any damage in 2011. It is known that there is not too much wear and tear besides, heat differences and frost affecting humid environments causes fragmentations and fractures due to the soft spongy nature of the Ahlat stone. Moisture-induced deterioration has observed on the areas of the stone contacting with water. It would be beneficial to make the necessary water isolation in the natural soil connection joints of the structure base. Freezingthawing, which is environmentally effective especially in cold periods, is one of the most important factors in the deterioration of the building materials on the site. These problems are partially observed on the bridge. Lichen formations which formed due to dry climate and high carbon content, are attract attention. Lichen formations can have negative effects on the appearance and properties of natural building stones over time. One of the most important factor negatively effects on historical buildings is water. Water, alone or in combination with other environmental factors, negatively affects the mechanical properties of building stones and accelerates deterioration. However, low water flow rate keeps the water damage on the bridge at very low levels. Generally, there are scours on bridge legs. There is a separation between the stones at one or two points of the bridge. Some of the bridge railing top stones is completely missing, and some of them have fracture damage. There are moisture induced traces on the bridge. Mass losses and color changes are exists on the front surface of the belt part of the bridge due to the effects of wear. Lichen occurrences are seen in different parts of bridge. On the other hand, joint losses have occurred in some parts. Observationally determined structural analysis form of the Emir 
Bayındır Bridge is shown in Table 1. The images of damage and deformations are shown in Figure 2.

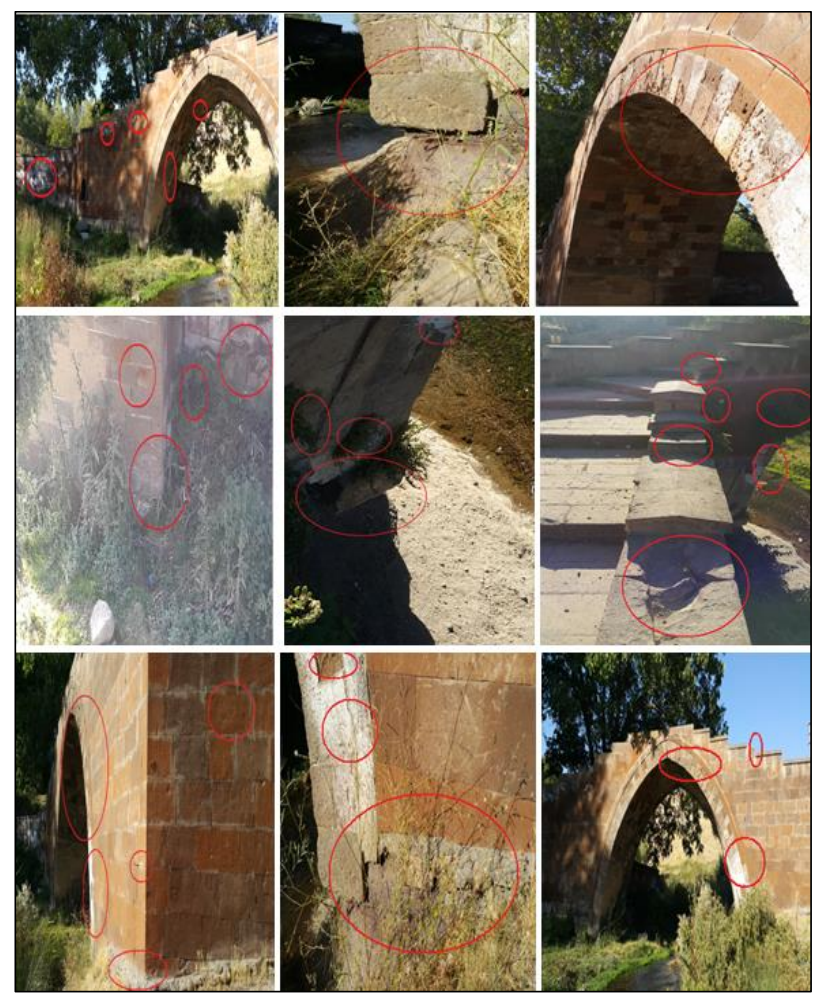

Figure 2. The observed damages in Emir Bayındır Bridge

The total length of this bridge is 45 meters, the main body length is 16.10 meters, the span width is 9.20 meters and the height of bridge is 6 meters. The structural analysis based design of the bridge, which is considered in the study, is shown in Figure 3.

Seismic analysis of inspected bridge in this study was carried out in SAP2000 software. The images of the finite element model obtained in the software are shown in Figure 4.

Finite element (FE) models provide cost effective solutions compared to the experimental alternative, but true success of FE techniques heavily depends on the constitutive models for the material and appropriate discretization of the continuum. Masonry is anisotropic due to the presence of discrete sets of horizontal and vertical mortar joints and possess orthotropic strength and softening characteristics, which depend not only on the properties of masonry constituent materials but also on their interaction reflecting the workmanship (Dhanasekar and Haider, 2008). The numerical modelling of masonry structures through the FEM is a very computationally demanding task because of two different aspects: on the one hand the typological characteristics of masonry buildings do not allow us to refer to simplified static schemes, on the other hand the mechanical properties of the material lead to a widely nonlinear behaviour whose prediction can be very tricky (Giordano et al., 2002; Nikoo et al., 2017)
Table 1. Observation based structural analysis form for Emir Bayındır Bridge

\begin{tabular}{|c|c|c|c|}
\hline Inspected Parameters & Yes & No & Annotation \\
\hline $\begin{array}{l}\text { Deterioration due to time } \\
\text { effect }\end{array}$ & $\mathrm{X}$ & & \\
\hline Effect of natural conditions & $\mathrm{X}$ & & \\
\hline Destruction of human & $\mathrm{X}$ & & \\
\hline Active use of building & $\mathrm{X}$ & & \\
\hline Heavy vehicle load effect & & $\mathrm{X}$ & \\
\hline Neglect & & $\mathrm{X}$ & \\
\hline $\begin{array}{l}\text { Random repairs and } \\
\text { renovations }\end{array}$ & & $\mathrm{X}$ & \\
\hline Is the originality preserved? & $\mathrm{X}$ & & \\
\hline $\begin{array}{l}\text { Deterioration on bridge } \\
\text { facades }\end{array}$ & & $\mathrm{X}$ & \\
\hline Unstable component stones & & $\mathrm{X}$ & \\
\hline Partially fracture and tear & & $\mathrm{X}$ & \\
\hline Calcification on the surfaces & $\mathrm{X}$ & & \\
\hline Wear of wall joints & $\mathrm{X}$ & & Very rare \\
\hline Scour on abutment & $\mathrm{X}$ & & \\
\hline $\begin{array}{l}\text { Mossing and vegetative } \\
\text { formations }\end{array}$ & $\mathrm{X}$ & & Partially \\
\hline Repaired & $\mathrm{X}$ & & \\
\hline $\begin{array}{l}\text { The presence of germinated } \\
\text { soil layer }\end{array}$ & $\mathrm{X}$ & & Partially \\
\hline Cracks & & $\mathrm{X}$ & \\
\hline Decay on the surface & $\mathrm{X}$ & & Very rare \\
\hline Surface darkening & $\mathrm{X}$ & & Very rare \\
\hline Mass loss & & $\mathrm{X}$ & \\
\hline Joint disorder & & $\mathrm{X}$ & \\
\hline Subsidence effects & & $\mathrm{X}$ & \\
\hline Joint mismatch & & $\mathrm{X}$ & \\
\hline Cracks due to plant roots & & $\mathrm{X}$ & \\
\hline $\begin{array}{l}\text { Horizontal and vertical } \\
\text { deformations }\end{array}$ & $\mathrm{X}$ & & Partially \\
\hline $\begin{array}{l}\text { Distribution of structural } \\
\text { system elements }\end{array}$ & \multicolumn{3}{|c|}{ Sufficient and proper } \\
\hline Protection measures & & $\mathrm{X}$ & Insufficient \\
\hline Water intrusion on structure & $\mathrm{X}$ & & \\
\hline Freeze - thaw effect & & $\mathrm{X}$ & \\
\hline Effect of nearby construction & & $\mathrm{X}$ & \\
\hline Color change & $\mathrm{X}$ & & \\
\hline Natural disaster effects & & $\mathrm{X}$ & \\
\hline Additional Explanations & \multicolumn{3}{|c|}{$\begin{array}{l}\text { One of the characteristics of the } \\
\text { Ahlat stone which used in bridge } \\
\text { construction is the color change } \\
\text { over time. Although the structure } \\
\text { is exposed to a few natural } \\
\text { disasters, there is no damage } \\
\text { caused by these disasters on the } \\
\text { bridge }\end{array}$} \\
\hline
\end{tabular}



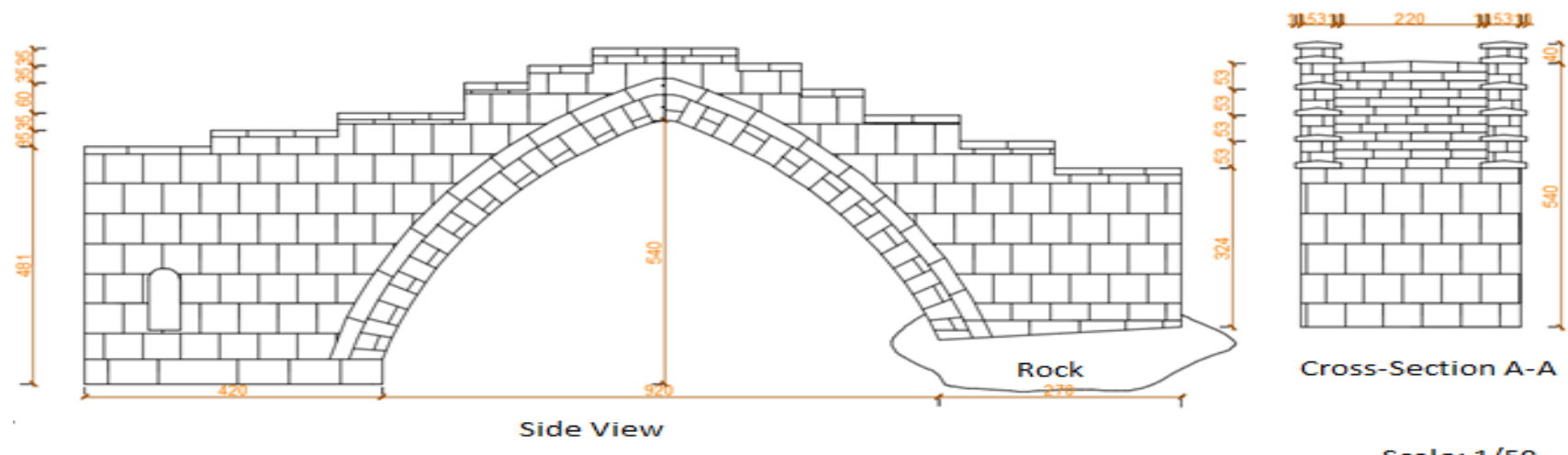

Cross-Section A-A

Scale: $1 / 50$

Figure 3. Dimensions of the inspected bridge

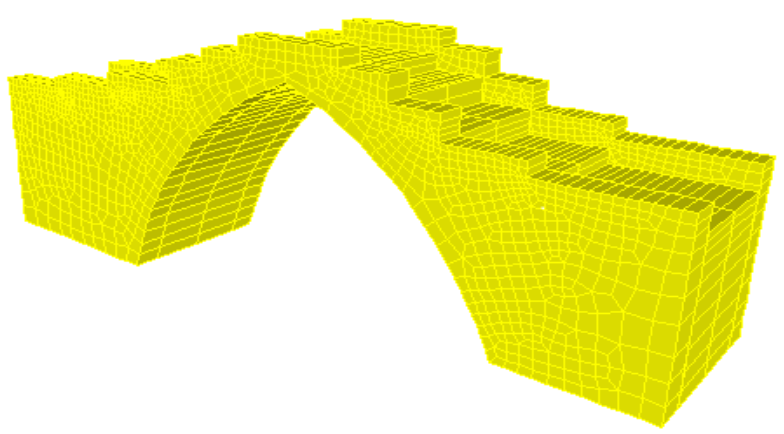

Figure 4. Bridge model created in software program

Material properties of building components have been taken from the results of previously studies in literature and recommended values for masonry structures in Turkish Earthquake Code (TEC, 2007). Modulus of elasticity and unit weight assumptions have been made under that Ahlat Stone that used in masonry structures with mortar was considered as a single material. Properties of materials were given in Table 2 .

Table 2. Properties of materials

\begin{tabular}{|c|c|c|c|c|}
\hline $\begin{array}{c}\text { Material } \\
\text { Type }\end{array}$ & $\begin{array}{c}\text { Modulus } \\
\text { of } \\
\text { Elasticity } \\
\left(\mathbf{k N} / \mathbf{m}^{2} \mathbf{)}\right.\end{array}$ & $\begin{array}{c}\text { Specific } \\
\text { Gravity } \\
\left(\mathbf{k N} / \mathbf{m}^{3} \mathbf{)}\right.\end{array}$ & $\begin{array}{c}\text { Unit } \\
\text { weight } \\
\mathbf{( t / \mathbf { m } ^ { 3 } \mathbf { ) }}\end{array}$ & $\begin{array}{c}\text { Poisson } \\
\text { Ratio }\end{array}$ \\
\hline Grave Stone & 5000000 & 24 & 2,45 & 0,2 \\
\hline
\end{tabular}

Two different load cases have been applied on the prepared desing model, taking into account the forces caused by the ground movements defined by the dead loads and the earthquake spectrum. The spectrum has been applied in two directions, as EQx and EQy. The spectrum curve that used for dynamic analysis of grave stone was given in Figure 5.
The sign conformance and direction assumptions of the elements used in the finite element model depending on the assumptions made by the software are shown in Figure 6.

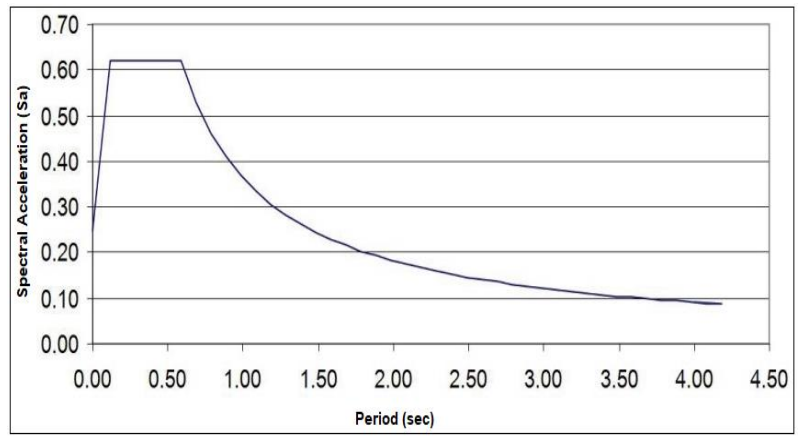

Figure 5. Spectrum curve for dynamic analysis
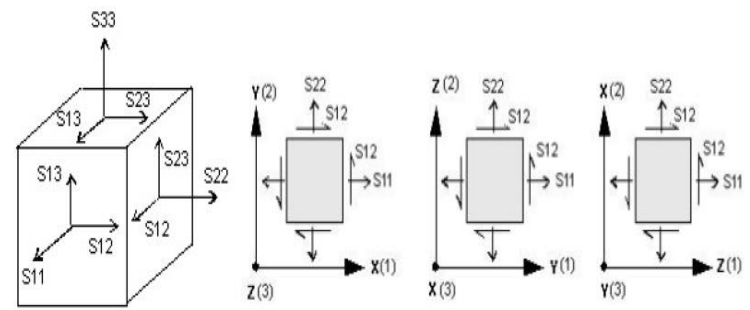

Figure 6. Sign conformance and direction assumptions (Dabanll, 2008)

As indicated in Figure 6; S11: vertical stress in the (X) direction, S22: vertical stress in the $(\mathrm{Y})$ direction, S33: vertical stress in the (z) direction, (S12 = S21): shear stresses in the XY plane.

The designed finite element model is composed of 7556 nodal points and 3924 solid elements. The dynamic features of the bridge have been determined by modal analysis. The first 70 modes that occurred in the structure were considered, when modal analyzes was carried out. Models with mass participation ratios of more than $80 \%$ in the $\mathrm{X}$ and $\mathrm{Y}$ directions are considered in the generated model. Therefore, it was observed that there was no need to take more modes. According to the model's modal analysis results; effective modes, natural vibration periods and mass participation ratios are shown in Table 3 and mode shapes 


\section{are shown in Figure 7}

Table 3. Effective mass participation ratios and modal analysis results of model

\begin{tabular}{|c|c|c|c|c|c|c|c|c|c|c|c|}
\hline Mod & Period & $\mathrm{U}_{\mathbf{x}}$ & $\mathrm{U}_{\mathbf{y}}$ & $\Sigma \mathrm{U}_{\mathbf{x}}$ & $\Sigma \mathrm{U}_{\mathbf{x}}$ & $\Sigma \mathrm{U}_{\mathbf{z}}$ & $\mathbf{R}_{\mathbf{x}}$ & $\mathbf{R}_{\mathbf{y}}$ & $\Sigma \mathbf{R}_{\mathbf{x}}$ & $\Sigma \mathbf{R}_{\mathbf{x}}$ & $\Sigma \mathbf{R}_{\mathbf{x}}$ \\
\hline 1 & 0,079915 & 0,00062 & 0,28875 & 0,00047 & 0,00062 & 0,28875 & 0,00047 & 0,44788 & 0,00063 & 0,09454 & 0,44788 \\
\hline 2 & 0,068632 & 0,00077 & 0,06744 & 0,00074 & 0,0014 & 0,35619 & 0,00121 & 0,13856 & 0 & 0,07644 & 0,58644 \\
\hline 3 & 0,058294 & 0,00072 & 0,03119 & 0,00073 & 0,00211 & 0,38737 & 0,00194 & 0,089964 & 0,00016 & 0,1291 & 0,67608 \\
\hline 4 & 0,046995 & 0,00052 & 0,00032 & 0,00061 & 0,00263 & 0,3877 & 0,00255 & 0,00044 & 0,00036 & 0,01103 & 0,67652 \\
\hline 5 & 0,04146 & 0,00076 & 0,00033 & 0,00095 & 0,00339 & 0,38803 & 0,0035 & 0 & 0 & 0,01467 & 0,67653 \\
\hline 6 & 0,035424 & 0,01797 & 0,01543 & 0,00336 & 0,02136 & 0,40346 & 0,00686 & 0,0154 & 0,00593 & 0,00079 & 0,69194 \\
\hline 7 & 0,033912 & 0 & 0,10193 & 0,00718 & 0,02137 & 0,50539 & 0,01404 & 0,07314 & 0,00224 & 0,01431 & 0,76508 \\
\hline 8 & 0,032252 & 0,15916 & 0,00948 & 0,0101 & 0,18053 & 0,51488 & 0,02414 & 0,00506 & 0,03456 & 0,00091 & 0,77014 \\
\hline 9 & 0,030912 & 0,01199 & 0,0006 & 0,01827 & 0,19252 & 0,51548 & 0,04241 & 0,00016 & 0,00454 & 0,00105 & 0,7703 \\
\hline 10 & 0,028192 & 0,00146 & 0,00294 & 0,07957 & 0,19397 & 0,51842 & 0,12198 & 0,00493 & 0,06894 & 0,06092 & 0,77523 \\
\hline 63 & 0,008332 & 0,04445 & 0,0005 & 0 & 0,79012 & 0,8201 & 0,81395 & 0,00033 & 0,0099 & 0,00157 & 0,92152 \\
\hline 64 & 0,008322 & 0,02827 & 0,00113 & 0,00049 & 0,81839 & 0,82122 & 0,81444 & 0,00076 & 0,01528 & 0,0002 & 0,92228 \\
\hline 65 & 0,008158 & 0,00284 & 0,00028 & 0,00021 & 0,82124 & 0,8215 & 0,81465 & 0,00015 & 0,00257 & 0,01429 & 0,92243 \\
\hline 66 & 0,00812 & 0 & 0,00164 & 0,00317 & 0,82124 & 0,82314 & 0,81782 & 0,00411 & 0,00363 & 0,00017 & 0,92653 \\
\hline 67 & 0,008066 & 0,00053 & 0,00013 & 0,00529 & 0,82177 & 0,82327 & 0,82311 & 0,00157 & 0,00369 & 0,00214 & 0,9281 \\
\hline 68 & 0,007998 & 0,00016 & 0 & 0,00252 & 0,82193 & 0,82327 & 0,82564 & 0,0003 & 0,00533 & 0,00281 & 0,9284 \\
\hline 69 & 0,007918 & 0,00351 & 0,00047 & 0,0021 & 0,82544 & 0,82375 & 0,82774 & 0,00172 & 0,01602 & 0 & 0,93012 \\
\hline 70 & 0,007806 & 0,00076 & 0 & 0,00013 & 0,8262 & 0,82378 & 0,82787 & 0,00038 & 0,00047 & 0,00582 & 0,93049 \\
\hline
\end{tabular}

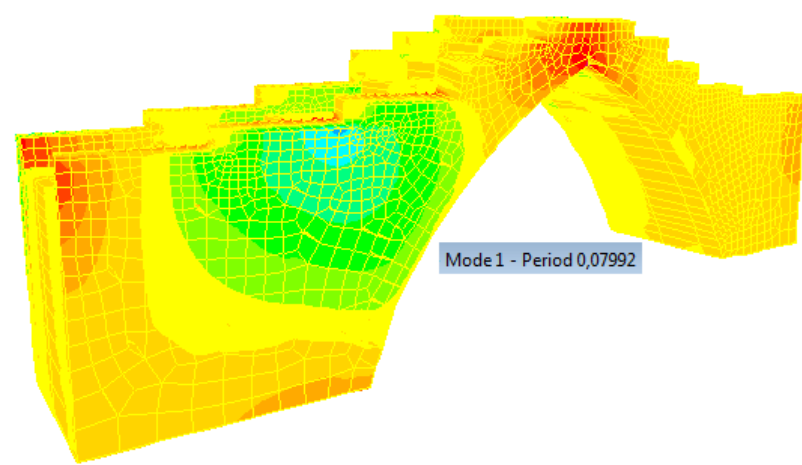

Şekil 7a. The first mode shape and period value obtained for the bridge model

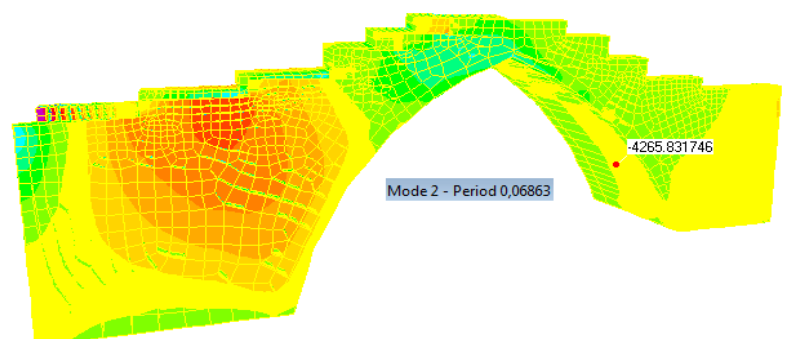

Şekil 7b. The second mode shape and period value obtained for the bridge model

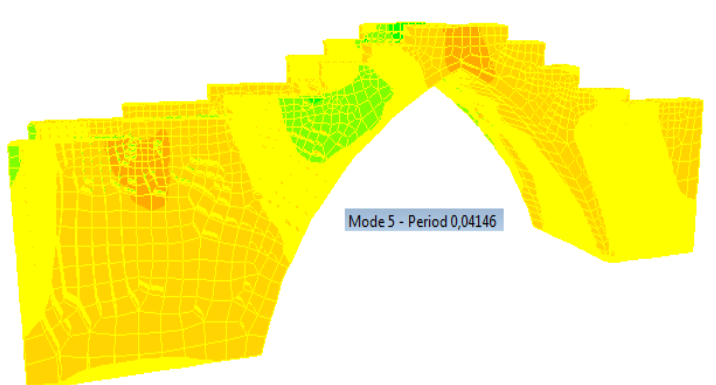

Şekil 7c. The 5th mode shape and period value obtained for the bridge model

The stress diagrams obtained for different load cases for S11 which is the vertical stress values in the $\mathrm{X}$ direction are shown in Figure 8.

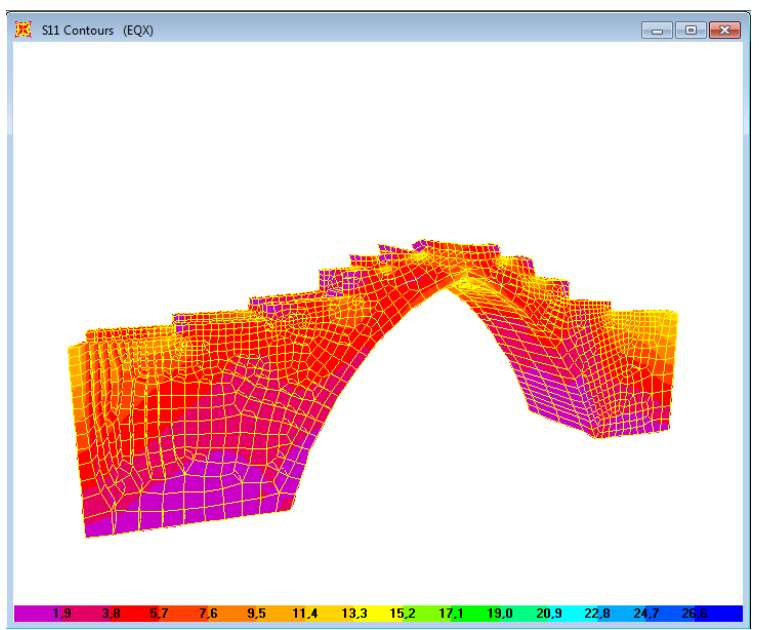

Figure 8a. S11 stress values for EQX load cases

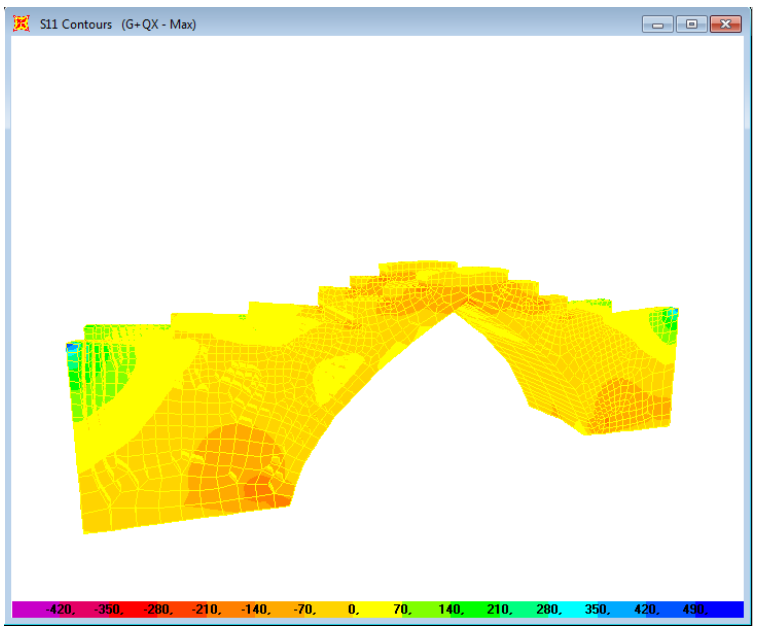

Figure 8b. S11 stress values for $\mathrm{G}+\mathrm{QX}$ load cases 


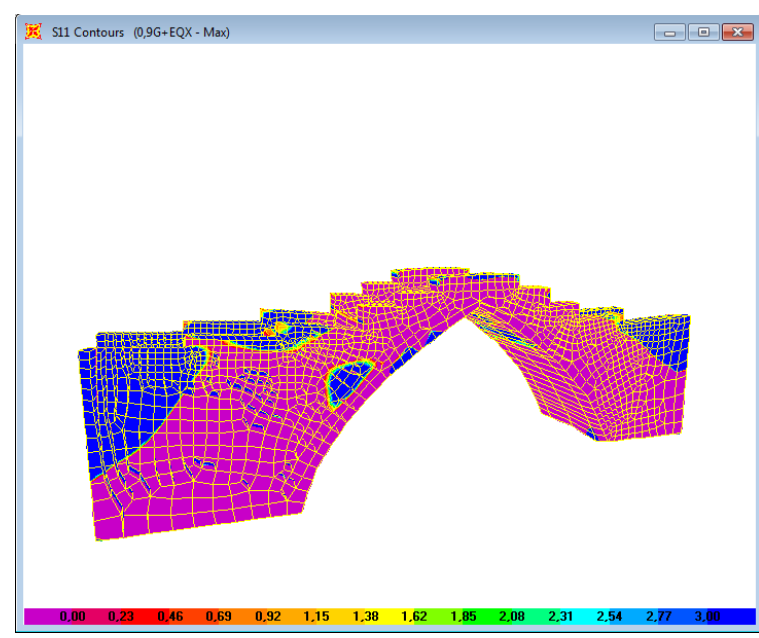

Figure 8c. S11 stress values for 0,9G+EQX load cases

The stress diagrams obtained for different load cases for S22 which is the vertical stress values in the $\mathrm{X}$ direction are shown in Figure 9.

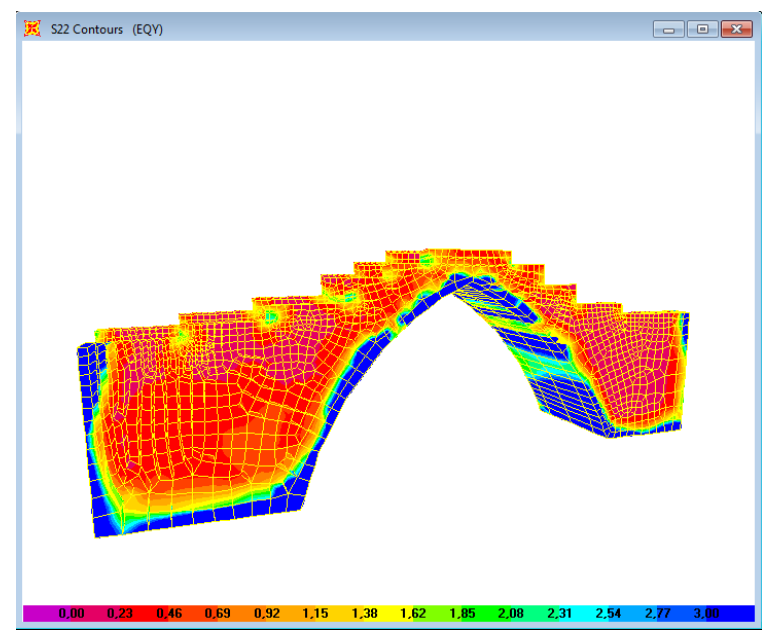

Şekil 9a. S22 stress values for EQY load cases

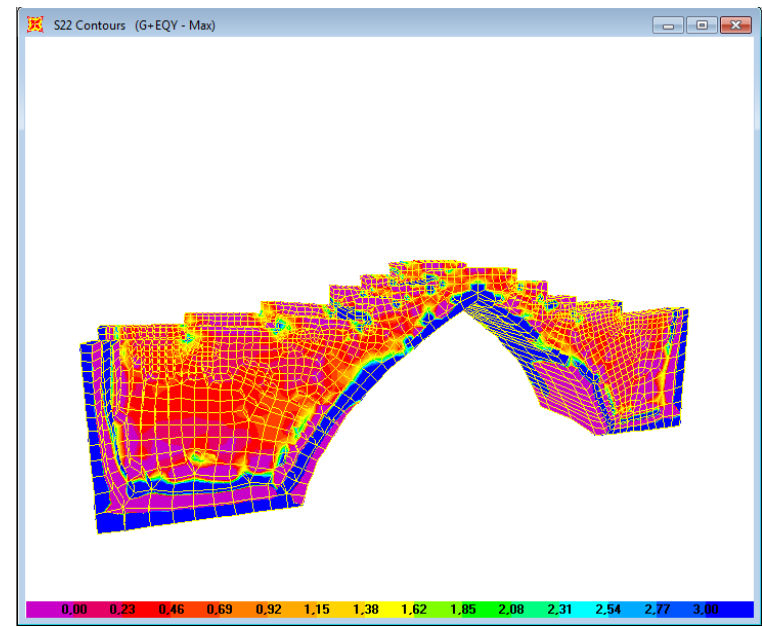

Şekil 9b. S22 stress values for G+EQY load cases

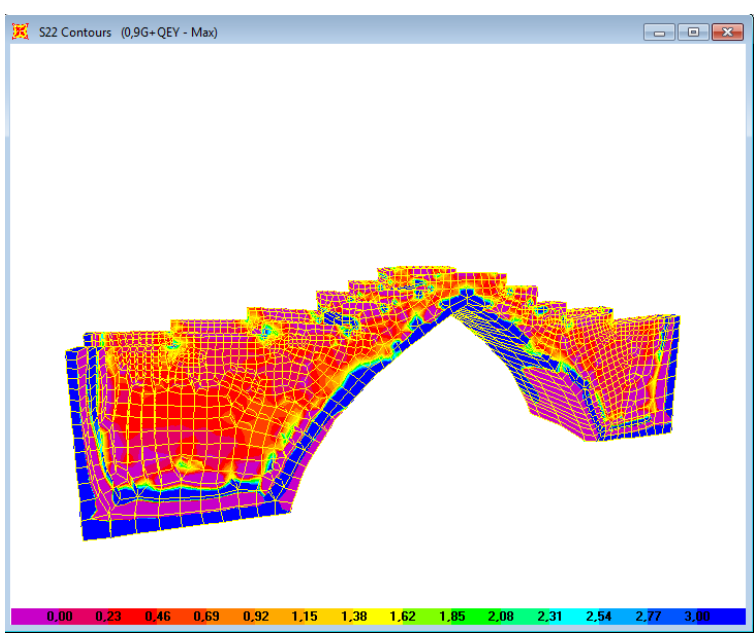

Şekil 9c. S22 stress values for 0,9G+EQY load cases

The stress diagrams obtained for different loading cases for S12 which is the shear stress values in the $\mathrm{X}-\mathrm{Y}$ direction are shown in Figure 10.

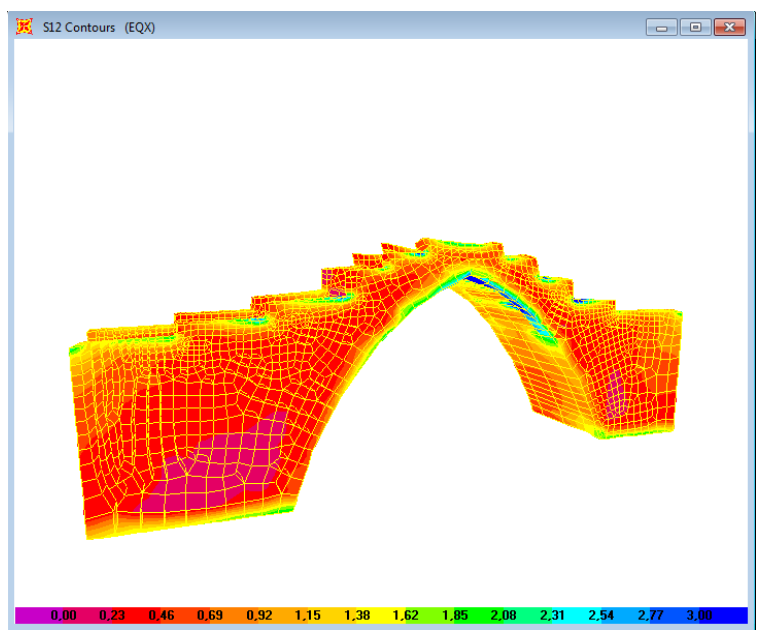

Şekil 10a. S12 stress values for EQX load cases

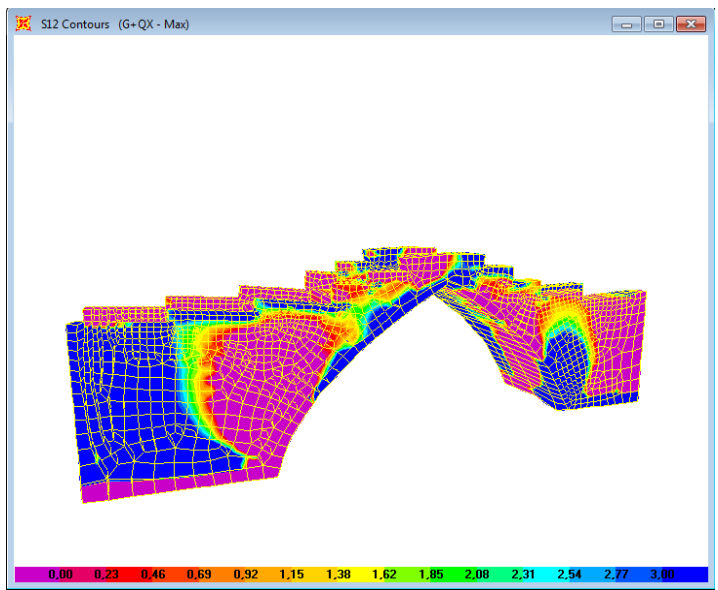

Şekil 10b. S12 stress values for $G+Q X$ load cases 


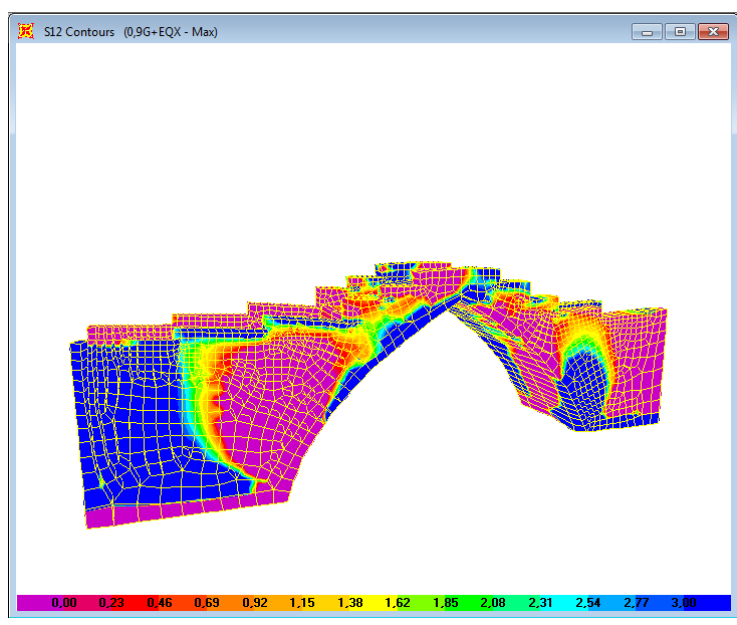

Şekil 10c. S12 stress values for $0,9 \mathrm{G}+\mathrm{EQX}$ load cases

The maximum tensile stress values obtained from the analysis results are given in Table 4 .

Table 4. Maximum tensile stresses obtained under earthquake effect

\begin{tabular}{|c|c|c|}
\hline Load Case & S11 (MPa) & S22(MPa) \\
\hline$G+Q E_{x}$ & 0,501 & 0,212 \\
\hline$G+\mathrm{QE}_{y}$ & 0,523 & 0,291 \\
\hline $0.9 \mathrm{G}+\mathrm{QE}_{x}$ & 0,452 & 0,192 \\
\hline $0.9 \mathrm{G}+\mathrm{QE}_{\mathrm{y}}$ & 0,474 & 0,271 \\
\hline $\mathrm{G}+\mathrm{QE}_{\mathrm{x}}+0,3 \mathrm{QE}_{\mathrm{y}}$ & 0,511 & 0,239 \\
\hline $\mathrm{G}+0,3 \mathrm{QEx}+\mathrm{QE}_{\mathrm{y}}$ & 0,526 & 0,294 \\
\hline
\end{tabular}

The maximum compressive stress values obtained from the analysis results are given in Table 5 .

Table 5. Maximum compressive stresses obtained under earthquake effect

\begin{tabular}{|c|c|c|}
\hline Load Cases & S11 (MPa) & S22(MPa) \\
\hline$G+Q E_{x}$ & 0,480 & 0,304 \\
\hline$G+Q E_{y}$ & 0,490 & 0,314 \\
\hline $0.9 G+Q_{x}$ & 0,433 & 0,274 \\
\hline $0.9 G+Q_{y}$ & 0,443 & 0,284 \\
\hline$G+Q E_{x}+0,3 Q_{y}$ & 0,485 & 0,308 \\
\hline$G+0,3 Q E_{x}+Q_{y}$ & 0,492 & 0,316 \\
\hline
\end{tabular}

The maximum shear stress values obtained from the analysis results are given in Table 6.

It can be observed that according to the different loading conditions considered in the study, the maximum tensile stress is $0.526 \mathrm{MPa}$, the maximum compressive stress is $0.492 \mathrm{MPa}$ and the maximum shear stress is $0.204 \mathrm{MPa}$.
Table 6. Maximum shear stresses obtained under earthquake effect

\begin{tabular}{|c|c|}
\hline Load Cases & S12 $(\mathrm{MPa})$ \\
\hline $\mathrm{G}+\mathrm{QE}_{\mathrm{x}}$ & 0,204 \\
\hline $\mathrm{G}+\mathrm{QE}_{\mathrm{y}}$ & 0,203 \\
\hline $0.9 \mathrm{G}+\mathrm{QE}_{\mathrm{x}}$ & 0,184 \\
\hline $0.9 \mathrm{G}+\mathrm{QE}_{\mathrm{y}}$ & 0,183 \\
\hline $\mathrm{G}+\mathrm{QEx}+0,3 \mathrm{QE}_{\mathrm{y}}$ & 0,131 \\
\hline $\mathrm{G}+0,3 \mathrm{QE}_{\mathrm{x}}+\mathrm{QE}_{\mathrm{y}}$ & 0,204 \\
\hline
\end{tabular}

All of these stresses were obtained from G + 0.3 QEX + QEy load case. Stresses that may occur on the bridge can be carried without any problems. However, calculations can be made on the bridge in future studies in order to different earthquake effects. Damages that may occur on the bridge over time, must be observed and timely intervened and by this way, bridge should be transferred to the next generation.

\section{Results}

In this study, a comprehensive study was carried out to determine the earthquake behavior of Ahlat Emir Bayindir Bridge located in Ahlat district. The model of the finite element was developed by using the solid elements of the constructed bridge. S11, S22 and S12 stresses were calculated for the generated finite element model. Also the mode shapes and period values of the bridge are obtained.

The necessary information was given about Ahlat Emir. Observation based structural analysis form has been filled as result of on-site inspections. Information about the damage that occurred over time on the bridge is given.

In time, the mass losses, wear and tears have occurred in the component stones of the bridge under natural conditions. In addition, lichen formations on these stones have also damaged the stones over time. Moisture influences have occurred on some stones place to place due to water effects. Authorities are continuing to work on fixing these occurred damages and protecting the stones from damage in the future.

Despite the natural events and negative conditions since many years, standing of the bridge enables to produce very accurate ideas in terms of the stability of these structures. This shows that historic buildings constructed by good engineering services.

\section{Acknowledgments}

This work is derived from a part of the master's thesis of the author named Barıș Antep.

\section{References}

Backer, L. D., Janssens, A., Steeman, M., Paepe, M. D., 2018. Evaluation of display conditions of the Ghent altarpiece at St. Bavo Cathedral. Journal of Cultural Heritage 29, 168-172

Beygu A. Ş., 1932. Ahlat Kitabeleri. İstanbul.

Computers and Structures, 2011. SAP 2000 V14.0.0 Software, Structural Analysis Program

Çulpan, C., 1975. Türk Taş Köprüleri, Ankara. 
Dabanlı. Ö., 2008. Tarihi yığma yapıların deprem performansının belirlenmesi, Yüksek Lisans Tezi, İstanbul Teknik Üniversitesi, İstanbul.

Dhanasekar, M., Haider, W., 2008. Explicit finite element analysis of lightly reinforced masonry shear walls. Computers \& Structures, 86(1), 15-26.

Erdil, B., Tapan, M., Akkaya, I., Korkut, F., 2018. Effects of structural parameters on seismic behaviour of historical masonry minaret, Periodica Polytechnica. Civil Engineering, 62(1), 148-161.

Giordano, A., Mele, E., De Luca, A., 2002. Modelling of historical masonry structures: comparison of different approaches through a case study. Engineering Structures, 24(8), 1057-1069.

Hadzima-Nyarko, M., Mišetić, V., Morić. D., 2017. Seismic vulnerability assessment of an old historical masonry building in Osijek, Croatia, using Damage Index. Journal of Cultural Heritage, 28, 140-150.

Hadzima-Nyarko, M., Pavić, G., Lešić, M., 2016. Seismic vulnerability of old confined masonry buildings in Osijek, Croatia. Earthquakes and Structures, 11(4), 629-648.

http://www.islamansiklopedisi.info/dia/pdf/c11/c110067.pdf (Access date:10.09.2017)

https://www.kulturportali.gov.tr/turkiye/bitlis/kulturenvanteri/e mr-bayindir-koprusu (Access date:10.09.2017)

Işık, M. F., Işık, E., Ülker, M., 2016. Establishment of urban memory system for Ahlat district, 1st International Mediterranaen Science and Engineering Congress, Adana, Turkey.

Issık, E., Aydın, M. C., Ülker, M., 2016a. Performance evaluation of a historical tomb and seismicity of the region. Bitlis Eren University, Journal of Science and Technology, 6(2), 59-65.

Işık, E., Velioğlu, E., Öztürk, G., 2016b. Determination of seismic safety of a historic masonry building in Bitlis, BEU Journal of Science, 5(1), 59-64.
Ișlk, M. F., Ișık, E., Bülbül, M. A., Karașin, İ.B., 2017. QR code application for geometric location and information of historical structures. In International Conference on Advanced Engineering Technologies (ICADET 2017), Turkey.

Issık, E., Antep, B., Büyüksarac, A., Issık, M. F., 2018. Observation of Behavior of the Ahlat Grave Stones (TURKEY) at Seismic Risk and Their Recognition by the QR Code. unpublished article.

Karaşin, İ. B., Işık, E., 2016. Protection of Ten-Eyed Bridge in Diyarbakır, Budownictwo i Architektura, 15(1), 87-94.

Mutlu, Ö., Şahin, A., 2016. Investigating the effect of modeling approaches on earthquake behavior of historical masonry minarets-Bursa Grand Mosque case study. Sigma, 7(2), 123-136.

Nikoo, M., Hadzima-Nyarko, M., Khademi, F., Mohasseb, S., 2017. Estimation of fundamental period of reinforced concrete shear wall buildings using self organization feature map. Structural Engineering and Mechanics, 63, 237-249.

Özbek, O., Akyıldız, M. H., Karașin, A. H., Öncü, M. E., Cetin, S. Y., 2017. Assessment of multi-storey masonry buildings in Sur region according to Turkish Seismic Code 2007. DUMF Journal of Engineering, 8(2), 395-402.

Preciado, A. Alejandro Ramirez-Gaytan, A., Salido-Ruiz, R. A., CaroBecerra, J. L., Lujan-Godinez, R., 2015. Earthquake risk assessment methods of unreinforced masonry structures: hazard and vulnerability. Earthquakes and Structures, 9 (4), 719-733.

Tabak N., 1972. Ahlat Türk Mimarisi, İstanbul.

Turkish Earthquake Code (TEC), 2007. Turkish earthquake codespecification for structures to be built in disaster areas, Turkey.

Uğurlu, M. A., Günaslan, S. E., Karaşin, A. H., 2017. Modelling and structural analysis of the Four-legged minaret. DUMF Journal of Engineering, 8(2), 413-421. 